\title{
A Study on the Diffusion of Mobile Payment Usage in China : Focusing on the Use Diffusion Model
}

\author{
Wei Wei Jiang ${ }^{1}$, Da Woon Wang ${ }^{2}$, Hye Kyong Choi ${ }^{3}$ \\ ${ }^{1}$ Master, Dept. of Consumer Studies, Ewha Womans University, South Korea, jwwweiwei@gmail.com \\ ${ }^{2}$ Ph.D. Candidate, Dept. of Consumer Studies, Ewha Womans University, South Korea, \\ wdw4599@ewhain.net \\ ${ }^{3}$ Professor, Dept. of Consumer Studies, Ewha Womans University, South Korea, chk@ewha.ac.kr \\ Corresponding author: Hye Kyong Choi
}

\begin{abstract}
Mobile payments have become a major payment method in China in a short period of time due to its convenience. This has gradually made the lives of Chinese consumers more mobile and improved their efficiency. In this regard, this study analyzed the current status of mobile payment usage in China based on the use diffusion model targeting 440 Chinese consumers. First, exploratory and confirmatory factor analysis was conducted to find out the influence and determinants of the spread of mobile payment use. As a result, it was classified into environmental creation, technology dependence, and technology anxiety. After that, the structural model was analyzed to verify the path hypothesis. As a result, environment creation and technical anxiety influenced the characteristics of mobile payment usage. And it was found that technology dependence, technology anxiety, and diversity among the characteristics of use had a significant effect on the diffusion outcome. In particular, technology anxiety has been shown to be an important factor that not only increases the spread and satisfaction of consumers, but also increases the intention to accept new technologies that will be introduced in the future. Therefore, research on consumer's technology anxiety is needed in the future, and this is expected to contribute to devising measures to increase consumer acceptance of technology.
\end{abstract}

Keywords: Mobile Payment, Use Diffusion Model, Technology Anxiety, Technology Acceptance

\section{Introduction}

Mobile payment technology has made rapid progress in recent years. Currently, China's mobile payment utilization rate is around $71.4 \%$, which is perceived to be simpler and safer than existing payment methods (cash, cards, etc.). Since its introduction, its use has expanded further. The advent of mobile payment has enabled consumers to do mobile shopping wherever there is a network without being limited by time and space.

According to the report of the Korea International Trade Association in 2018, the amount of mobile payments used in China was 190.5 trillion yuan[1]. This figure is an increase of about $50 \%$ from the previous year, showing steady growth since the introduction of mobile payment. It indicates that mobile payments have became a major payment method in China. In the digital market forecast 2020 report, the proportion of mobile payments in the overall payment market is estimated to increase by nearly $20 \%$ from $65.4 \%$ in 2019 to $82.8 \%$ in 2024[2]. This method accounts for an overwhelming percentage compared to other payment methods.

Received: April 14, 2021; $1^{\text {st }}$ Review Result: May 31, 2021; $2^{\text {nd }}$ Review Result: July 21, 2021

Accepted: August 30, 2021 
China's payment method share in 2019

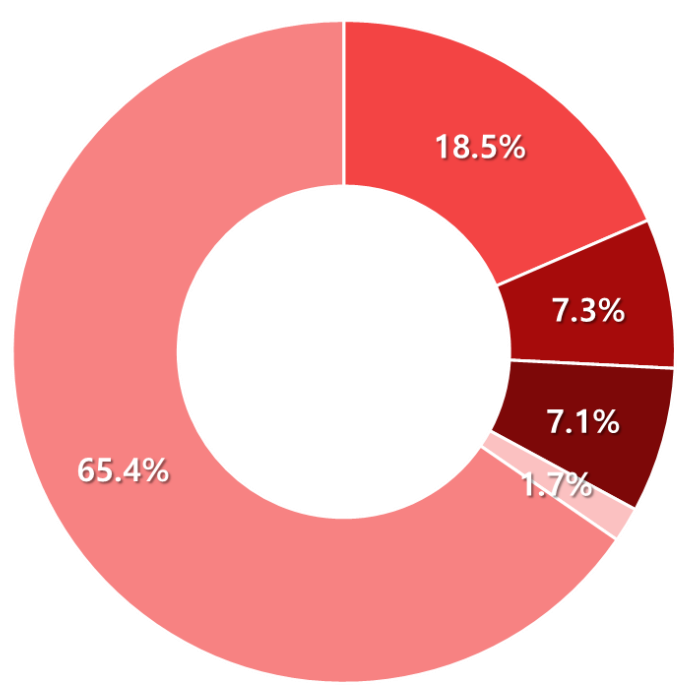

- Credit Card - Account Transfer
China's payment method share in 2024

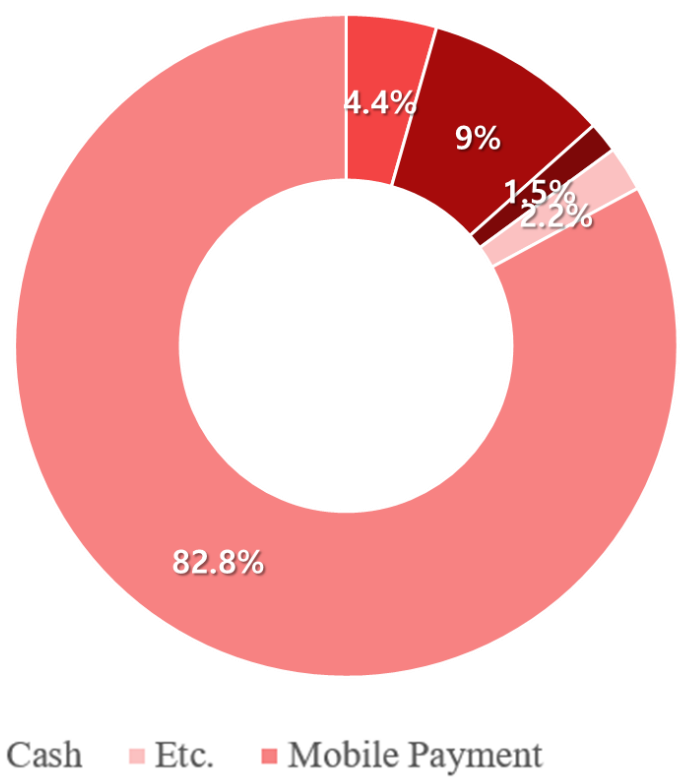

[Fig. 1] 1 Comparison of China's Payment Method Share

It is necessary for Korean companies to flexibly accept mobile payments as an inevitable trend and develop mobile payment services for consumers. However, Korea is currently limited in terms of mobile payment's market and system compared to other countries. To this end, this study is aimed to analyze the current situation and trend of mobile payments in China using the Use Diffusion Model. Focusing on the situation and factors influencing the use of mobile payments, the researchers intend to discover the usage characteristics of mobile payments. This will enable the prediction of acceptance and diffusion of new technologies among consumers in the future.

\section{Contents}

\subsection{Use Diffusion Model}

The technology acceptance model has been widely used in many studies examining consumer attitudes and behavioral intentions in relation to new technologies. The technology acceptance model (TAM) suggested that consumers accept technology through a set decision-making process. However, in recent years, it has been pointed out that it cannot be considered that there are many cases in which technology is accepted due to the inevitable trend such as the spread of smartphones or the introduction of compulsory technology without going through such a decision-making process. Also it is controversial that the process of technology acceptance cannot be analyzed[3]. So, some scholars had proposed a Use Diffusion model by changing the research direction into a format for how to use it beyond the acceptance of technology. In the case of China, which is the subject of this study, the growth of mobile payments was achieved in a short period under the leadership of the government. Therefore, moving on from the previous study that analyzed mobile payment based on the technology acceptance model[4-6], this study intends to analyze the mobile payment system based on the use diffusion model.

The use diffusion model represents the form and extent of people using new technologies based on two dimensions: rate and variety of use. Consumers' usage patterns are divided into four types: intense use, non-specialized use, specialized use, and limited use[7]. The specific use diffusion model is shown 
in [Fig. 2] below.

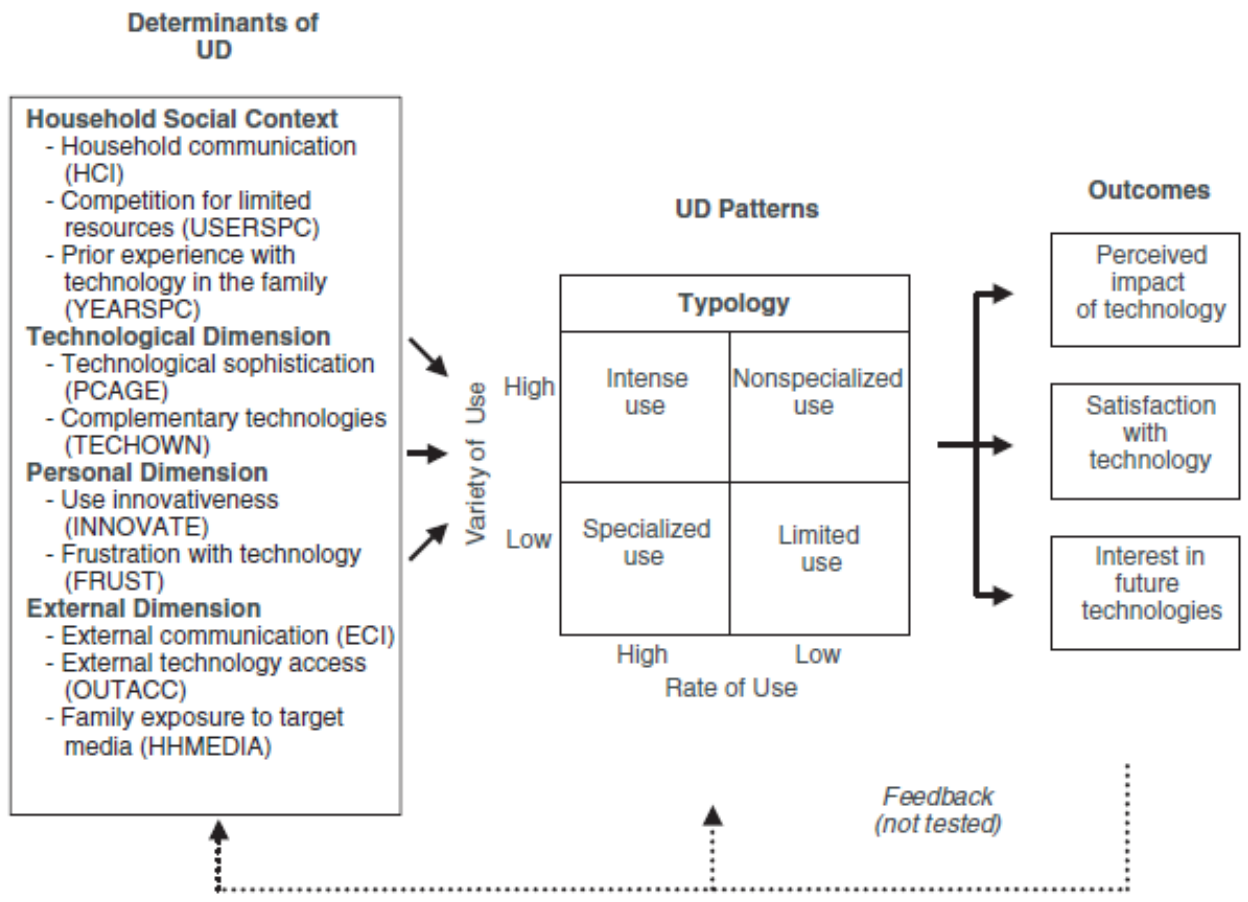

[Fig. 2] Use Diffusion Model

\subsection{Research Question and Research Model}

This study seeks to find how mobile payment use diffusion factors affect usage diffusion characteristics and usage diffusion results among Chinese consumers. It will also determine how usage diffusion characteristics affect usage diffusion results. Specific research issues are as follows.

Research Q1. How do the determinants of Use Diffusion for mobile payments affect the Use Diffusion patterns and outcomes?

Research Q2. How do the determinants of Use Diffusion for mobile payments affect the outcomes mediated by the Use Diffusion patterns?

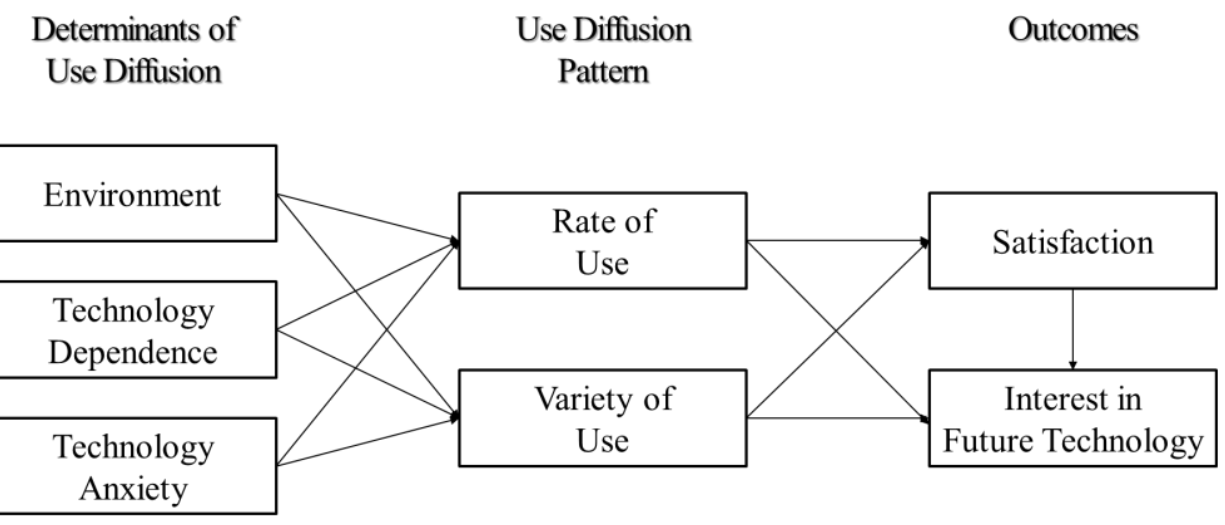

[Fig. 3] Research Model 


\subsection{Research Method}

\subsubsection{Data Collection}

This used the data collected through the Chinese research company to analyze the mobile payment usage of Chinese consumers using quadratic exploitation[8]. The data were intended for Chinese consumers aged 20 to 59 who had experience using mobile payments. In order to ensure the reliability of the data of the survey subjects, the survey area was limited to Beijing-Tianjin-Habuk with similar income and consumption levels. As a results, a total of 440 people were selected to participate in this study.

\subsubsection{Research Subject and Data}

There are 165 men(35.5\%) and 275 women(62.5\%) among the participants. They mainly graduated from universities $(298,67.7 \%)$. And they usually work in office jobs $(184,41.8 \%) .149$ people(33.9\%) earn between 4,000 and 6,000 a month[8]. Specific details are as follows [Table 1].

[Table 1] General Characteristics of Participants $(n=440)$

\begin{tabular}{|c|c|c|c|}
\hline \multicolumn{2}{|c|}{ Classification } & $\mathrm{N}$ & $\%$ \\
\hline \multirow{2}{*}{ Gender } & Male & 165 & 37.5 \\
\hline & Female & 275 & 62.5 \\
\hline \multirow{4}{*}{ Age } & $20-29$ & 128 & 29.1 \\
\hline & $30-39$ & 167 & 38.0 \\
\hline & $40-49$ & 76 & 17.3 \\
\hline & $50-59$ & 69 & 15.7 \\
\hline \multirow{4}{*}{ Education } & High school & 65 & 14.8 \\
\hline & College graduate & 39 & 8.9 \\
\hline & University graduate & 298 & 67.7 \\
\hline & Graduagte student & 38 & 8.6 \\
\hline \multirow{8}{*}{ Occupation } & Student & 54 & 12.3 \\
\hline & Office worker & 184 & 41.8 \\
\hline & Senior management & 26 & 5.9 \\
\hline & Professional & 62 & 14.1 \\
\hline & Self-employed & 41 & 9.3 \\
\hline & Housewife & 15 & 3.4 \\
\hline & Incooupation & 17 & 3.9 \\
\hline & Etc. & 41 & 9.3 \\
\hline \multirow{7}{*}{$\begin{array}{c}\text { Monthly } \\
\text { Income } \\
\text { (Chinese Yuan) }\end{array}$} & Less than 2,000 & 44 & 10.0 \\
\hline & $2,000-4,000$ & 74 & 16.8 \\
\hline & $4,000-6,000$ & 149 & 33.9 \\
\hline & $6,000-8,000$ & 73 & 16.6 \\
\hline & $8,000-10,000$ & 33 & 7.5 \\
\hline & $10,000-12,000$ & 29 & 6.6 \\
\hline & More than 12,000 & 30 & 8.6 \\
\hline \multicolumn{2}{|c|}{ Total } & 440 & 100 \\
\hline
\end{tabular}




\subsubsection{Research Instruments}

The operational definition and measurement of each variable was based on prior research. First, indicators related to mobile payment characteristics, technology dimensions, individual dimensions, and external dimensions use a variant of the scales of prior research to fit the context of this study[7][9-16]. Specific details are shown in [Table 2] below.

[Table 2] Indicator

\begin{tabular}{|c|c|c|c|}
\hline Indicators & $\mathrm{N}$ & Scale & Reference \\
\hline Sociodemographic Characteristics & 7 & Nominal scale & {$[3]$} \\
\hline Mobile Payment Characteristics & 7 & Nominal scale & {$[3]$} \\
\hline Mobile Payment Usage Frequency & 1 & Nominal scale & {$[3]$} \\
\hline Mobile Payment Usage Diversity & 2 & Nominal scale & {$[3]$} \\
\hline $\begin{array}{c}\text { Technology Dimensions } \\
\text { Individual Dimensions } \\
\text { External Dimensions }\end{array}$ & 33 & 5-point Likert scale & {$[6]$} \\
\hline Mobile Payment Recognition & 18 & 5-point Likert scale & {$[3]$} \\
\hline Mobile Payment Satisfaction & 1 & 5-point Likert scale & [6] \\
\hline
\end{tabular}

\subsubsection{Analysis Method}

For the data analysis of this study, a statistical analysis on survey data using SPSS Statistic was conducted. Prior to a full-fledged research model test, the researchers performed an exploratory factor analysis and reliability analysis on the mobile payment use diffusion impact factors to extract the variables and factors suitable for input into the research model. Finally, in order to determine the effect of subsequent mobile payment usage diffusion factors on usage characteristics, and the effect of usage characteristics on usage results, the researchers analyzed the confirmative factor analysis and intensive feasibility for endogenous and exogenous variables, and later structural model verification.

\section{Results}

\subsection{Characteristics of Consumers' Mobile Payment Usage}

Frequency analysis was conducted to identify the characteristics of consumers' mobile payment usage. Most of the participants $(302,68.6 \%)$ have used mobile payments for more than two years. Specific details are as follows [Table 3][Table 4].

[Table 3] Frequency of Mobile Payment Usage $(n=440)$

\begin{tabular}{|c|c|c|}
\hline & $\mathrm{N}$ & $\%$ \\
\hline At least once a week & 23 & 5.2 \\
\hline 2-3 times a week & 54 & 12.3 \\
\hline 4-5 times a week & 47 & 10.7 \\
\hline Almost everyday & 186 & 42.3 \\
\hline Use several times daily & 130 & 29.5 \\
\hline Total & 440 & 100.0 \\
\hline
\end{tabular}


[Table 4] Period of Mobile Payment Usage ( $\mathrm{n}=440)$

\begin{tabular}{|c|c|c|}
\hline & $\mathrm{N}$ & $\%$ \\
\hline Less than 6 months & 12 & 2.7 \\
\hline 6 months - 1 year & 25 & 5.7 \\
\hline 1 year - 2 years & 101 & 23.0 \\
\hline More than 2 years & 302 & 68.6 \\
\hline Total & 440 & 100.0 \\
\hline
\end{tabular}

\subsection{Exploratory Factor Analysis: Determinants of Use Diffusion}

To analyze the determinants of use diffusion for mobile payment, an exploratory factor analysis was conducted through the varimax rotation method. As a result, 31 of the 52 questions were deleted and a total of 21 questions were included in the final analysis. The KMO test results showed a value of 0.940 and a Bartlett's constructive test value of $6777.979(\mathrm{P}<.001)$, indicating that the use of factor analysis was appropriate. After that, we labeled these variables for next Confirmatory Factor Analysis. Specific exploratory factor analysis results are as follows [Table 5].

[Table 5] EFA and Reliability Analysis Results $(n=440)$

\begin{tabular}{|c|c|c|c|c|}
\hline Variable & & Questions & Reliability & $\begin{array}{l}\text { Observed } \\
\text { Variable }\end{array}$ \\
\hline \multirow{18}{*}{$\begin{array}{l}\text { Independent } \\
\text { Variable }\end{array}$} & \multirow{8}{*}{$\begin{array}{l}\text { Factor } 1 \\
\text { Environment }\end{array}$} & People around me have a lot of experience with mobile payments. & \multirow{8}{*}{0.921} & E1 \\
\hline & & There are many payment machines that allow to use mobile payments in stores. & & E2 \\
\hline & & Mobile payment applications can be installed on any cell phone. & & E3 \\
\hline & & I do a lot of money transactions with people around me via mobile payments. & & E4 \\
\hline & & I can use mobile payments when I spend online. & & E5 \\
\hline & & Everyone around me uses mobile payments. & & E6 \\
\hline & & $\begin{array}{l}\text { I think the screen for mobile payments is reasonable, simple, and easy to } \\
\text { understand. }\end{array}$ & & E7 \\
\hline & & The external Internet infrastructure is well established. & & E8 \\
\hline & \multirow{6}{*}{$\begin{array}{c}\text { Factor } 2 \\
\text { Dependence } \\
\text { on } \\
\text { Technology }\end{array}$} & I can't imagine a life without mobile payment. & \multirow{6}{*}{0.888} & D1 \\
\hline & & $\begin{array}{l}\text { I think technology to protect privacy should be strengthened more because my } \\
\text { secret might be known to others. }\end{array}$ & & D2 \\
\hline & & $\begin{array}{l}\text { Using mobile payments is more helpful to households than not using mobile } \\
\text { payments. }\end{array}$ & & D3 \\
\hline & & Mobile phone is as important as other electronics. & & D4 \\
\hline & & I often feel uncomfortable when mobile payments are not going well. & & D5 \\
\hline & & Mobile payment increases my consumption. & & D6 \\
\hline & \multirow{4}{*}{$\begin{array}{c}\text { Factor } 3 \\
\text { Technology } \\
\text { Anxiety }\end{array}$} & I often feel frustrated when I use mobile payments. & \multirow{4}{*}{0.857} & A1 \\
\hline & & It is difficult to use mobile payment. & & A2 \\
\hline & & I made a mistake when I used mobile payment. & & A3 \\
\hline & & $\begin{array}{l}\text { I'm worried when I use mobile payments because I'm afraid I'll lose money by } \\
\text { my mistake }\end{array}$ & & A4 \\
\hline \multirow{2}{*}{$\begin{array}{l}\text { Dependent } \\
\text { Variable }\end{array}$} & \multirow{2}{*}{$\begin{array}{l}\text { Factor } 4 \\
\text { Interest in } \\
\text { Future }\end{array}$} & I want to try a new payment method that other people teach me. & \multirow{2}{*}{0.866} & N1 \\
\hline & & I think I am a fashionable person when I use mobile payments. & & $\mathrm{N} 2$ \\
\hline
\end{tabular}




\begin{tabular}{|c|l|l|c|c|}
\hline & Technology & I think I can easily accept the new mobile payment method. & N3 \\
\hline \multicolumn{3}{|c|}{$\mathrm{KMO}=0.940$, Bartlett test $=6777.979(\mathrm{p}<.001)$} \\
\hline
\end{tabular}

\subsection{Confirmatory Factor Analysis and Verification of Convergent Validity}

Confirmatory factor analysis verifies the relationship between the latent variable and the observed variable. It is useful for measuring construct validity because it can evaluate the overall fit of the structural equation model[17]. The CFI, GFI, and TLI values above 0.9[18] but RMSEA below 0.05 is considered a good fit model[19]. The RMSEA below 0.08 is considered a good model, but above 0.10 is judged as a bad model. As a result of the analysis, at first, it is found that the GFI did not meet the recommended criteria[20]. The factor load of Q.A3 is less than 0.5 , so the analysis was performed again after removing Q.A3. After removing this question, the model fit met the criteria for fitness $\left(\chi^{2}=555.998\right.$ $(\mathrm{df}=212, \mathrm{p}<0.001), \mathrm{CMIN} / \mathrm{DF}=2.623, \mathrm{CFI}=0.947, \mathrm{TLI}=0.937, \mathrm{RMSEA}=0.061, \mathrm{GFI}=0.904)[20] . \mathrm{A}$ total of 20 questions were included in the final analysis.

Afterwards, the factor loads, composite reliability, and average variance extracted (AVE) values were examined to verify the convergent Validity. As a result of the analysis, the factor loads of all items were found to be 0.5 or more and the t-value was also greater than 1.965 , indicating that the observed variables effectively explained the latent variables. The composite reliability satisfies the criterion as all latent variables are .854 or higher, and average variance extracted is 0.5 or higher.

As a result of comparing the average variance extracted value and the correlation coefficient value between factors to verify the discriminant validity, the average variance extracted for each factor is found to be higher than the squared correlation coefficient of the two factors. Therefore, there is no problem with the discriminant validity between all factors.

[Table 6] CFA, Reliability and AVE results $(\mathrm{n}=440)$

\begin{tabular}{|c|c|c|c|c|c|}
\hline $\begin{array}{c}\text { Observed } \\
\text { Variable }\end{array}$ & $\begin{array}{l}\text { Latent } \\
\text { Factors }\end{array}$ & $\begin{array}{c}\text { Standardized } \\
\text { Coefficients }\end{array}$ & T-value & $\begin{array}{l}\text { Conposite } \\
\text { Reliability }\end{array}$ & Reliability \\
\hline E1 & \multirow{8}{*}{$\begin{array}{c}\text { Factor } 1 \\
\text { Environment }\end{array}$} & 0.735 & $13.215^{* * *}$ & \multirow{8}{*}{0.951} & \multirow{8}{*}{0.708} \\
\hline E2 & & 0.737 & $13.241^{* * *}$ & & \\
\hline E3 & & 0.845 & $14.674 * * *$ & & \\
\hline $\mathrm{E} 4$ & & 0.849 & $14.719^{* * *}$ & & \\
\hline E5 & & 0.786 & $13.907 * * *$ & & \\
\hline E6 & & 0.804 & $14.149 * * *$ & & \\
\hline E7 & & 0.831 & $14.499 * * *$ & & \\
\hline E8 & & 0.633 & - & & \\
\hline D1 & \multirow{6}{*}{$\begin{array}{c}\text { Factor } 2 \\
\text { Dependence } \\
\text { on } \\
\text { Technology }\end{array}$} & 0.843 & $16.280^{* * *}$ & \multirow{6}{*}{0.915} & \multirow{6}{*}{0.643} \\
\hline $\mathrm{D} 2$ & & 0.681 & $13.358 * * *$ & & \\
\hline D3 & & 0.786 & $15.280^{* * *}$ & & \\
\hline D4 & & 0.836 & $16.162 * * *$ & & \\
\hline D5 & & 0.701 & $13.723^{* * * *}$ & & \\
\hline D6 & & 0.695 & - & & \\
\hline A1 & \multirow{3}{*}{$\begin{array}{l}\text { Factor } 3 \\
\text { Technology } \\
\text { Anxiety }\end{array}$} & 0.955 & - & \multirow{3}{*}{0.854} & \multirow{3}{*}{0.669} \\
\hline $\mathrm{A} 2$ & & 0.924 & $28.348^{* * *}$ & & \\
\hline $\mathrm{A} 4$ & & 0.612 & $14.846^{* * *}$ & & \\
\hline
\end{tabular}




\begin{tabular}{|c|c|c|c|c|c|}
\hline N1 & \multirow{3}{*}{$\begin{array}{l}\text { Factor } 4 \\
\text { Interest in } \\
\text { Future } \\
\text { Technology }\end{array}$} & 0.848 & - & \multirow{3}{*}{0.897} & \multirow{3}{*}{0.744} \\
\hline N2 & & 0.811 & $20.129 * * *$ & & \\
\hline N3 & & 0.824 & $20.638 * * *$ & & \\
\hline \multicolumn{6}{|c|}{$\chi 2=555.998(\mathrm{df}=212, \mathrm{p}<0.001), \mathrm{CMIN} / \mathrm{DF}=2.623, \mathrm{CFI}=0.947, \mathrm{TLI}=0.937, \mathrm{RMSEA}=0.061, \mathrm{GFI}=0.904$} \\
\hline
\end{tabular}

[Table 7] Verification of Discriminant Validity $(n=440)$

\begin{tabular}{|c|c|c|c|c|}
\hline & Environment & $\begin{array}{c}\text { Technology } \\
\text { Dependence }\end{array}$ & $\begin{array}{c}\text { Technology } \\
\text { Anxiety }\end{array}$ & $\begin{array}{c}\text { Interest in } \\
\text { Future Technology }\end{array}$ \\
\hline Environment & .708 & .772 & .077 & .687 \\
\hline $\begin{array}{c}\text { Technology } \\
\text { Dependence }\end{array}$ & .596 & .643 & .280 & .751 \\
\hline $\begin{array}{c}\text { Technology Anxiety } \\
\begin{array}{c}\text { Interest in } \\
\text { Future Technology }\end{array}\end{array}$ & .006 & .078 & .669 & .389 \\
\hline
\end{tabular}

* Above diagonal: Correlation coefficient, Diagonal: AVE, Below diagonal: Squared correlation coefficient

\subsection{Path Analysis}

The path hypothesis established in this study was verified. In [Table 4], the path from environment to rate and from environment and technology anxiety to variety are found to be significant. On the other hand, it is found that technology dependence do not affect rate or variety. Among the determinants of use diffusion for mobile payment, only environment and technology anxiety are found to have a significant influence on rate and variety.

And we tried to analyze the effect of the mediation of use diffusion patterns on the outcomes. At first in the case of satisfactions, it is found that only the path from the technology anxiety to satisfaction is statistically significant.

In the case of interest in future technology, it has more causalities with the determinants of use diffusion compared to satisfaction. The path from technology dependence, technology anxiety and variety to interest in future technology is found to be significant. And the path from mobile payment satisfaction to the interest in future technology is also found to be significant.

[Table 8] Path Coefficient of Research Model $(n=440)$

\begin{tabular}{|l|c|c|c|}
\hline \multicolumn{1}{|c|}{ Path } & $\begin{array}{c}\text { Unstandardized } \\
\text { Coefficients }\end{array}$ & $\begin{array}{c}\text { Standard } \\
\text { Error }\end{array}$ & $\begin{array}{c}\text { Standardized } \\
\text { Coefficients }\end{array}$ \\
\hline Environment $\rightarrow$ Rate & 0.556 & 0.187 & $0.260^{* *}$ \\
\hline Technology Dependence $\rightarrow$ Rate & 0.132 & 0.180 & 0.067 \\
\hline Technology Anxiety $\rightarrow$ Rate & -0.079 & 0.050 & -0.081 \\
\hline Environment $\rightarrow$ Variety & 0.748 & 0.122 & $0.449^{* * *}$ \\
\hline Technology Dependence $\rightarrow$ Variety & 0.172 & 0.112 & 0.112 \\
\hline Technology Anxiety $\rightarrow$ Variety & 0.262 & 0.032 & $0.343^{* * *}$ \\
\hline Environment $\rightarrow$ Satisfaction & 0.195 & 0.139 & 0.131 \\
\hline Technology Dependence $\rightarrow$ Satisfaction & 0.231 & 0.126 & 0.167 \\
\hline Technology Anxiety $\rightarrow$ Satisfaction & -0.089 & 0.039 & $-0.130^{*}$ \\
\hline
\end{tabular}




\begin{tabular}{|c|c|c|c|}
\hline Rate $\rightarrow$ Satisfaction & 0.040 & 0.034 & 0.057 \\
\hline Variety $\rightarrow$ Satisfaction & 0.025 & 0.056 & 0.028 \\
\hline Environment $\rightarrow$ Interest in Future Technology & 0.165 & 0.085 & 0.121 \\
\hline Technology Dependence $\rightarrow$ Interest in Future Technology & 0.431 & 0.080 & $0.340 * * *$ \\
\hline Technology Anxiety $\rightarrow$ Interest in Future Technology & 0.064 & 0.024 & $0.102 * *$ \\
\hline Rate $\rightarrow$ Interest in Future Technology & 0.007 & 0.020 & 0.010 \\
\hline Variety $\rightarrow$ Interest in Future Technology & 0.384 & 0.035 & $0.465 * * *$ \\
\hline Satisfaction $\rightarrow$ Interest in Future Technology & 0.104 & 0.029 & $0.113 * * *$ \\
\hline
\end{tabular}

\section{Discussion}

This study applied the characteristics of Chinese consumers' mobile payment usage to the use diffusion model and analyzed the factors influencing the usage spread and the results. The discussions and implications are as follow.

First, based on importance of infrastructure. Among the determinants of use diffusion, the environment of the mobile payment does not affect acceptance or satisfaction of new technologies, but it has been shown to affect both the rate and variety of use. This suggests the importance of infrastructure to use technology. Therefore, it will be essential to have an infrastructure to spread new technologies.

Second, based on use diffusion patterns for accepting future technology. Among Chinese consumers, variety has a positive effect on the interest in future technology. This is expected to increase acceptance when new technologies are introduced in the future, although the use diffusion patterns of mobile payment have little influence as a factor that increases consumers' satisfaction. These can be interpreted that mobile payment is essential regardless of the satisfaction of Chinese consumers, as it has spread from the government's initiative and has become the main payment method. Therefore, it seems that the rate and variety of use did not affect the consumer's satisfaction of mobile payment.

Third, based on the influence of technology anxiety. Technology anxiety has affected the use diffusion patterns and outcomes. First of all, technology anxiety has been shown to have a positive effect on the variety of use. It seems that consumers are trying to disperse the risk by using variety of platforms. In addition, technology anxiety has been shown to have a negative effect on the satisfaction among users and a positive effect on their interest in future technology. It seems that technology anxiety decreases user satisfaction and raises expectations for the release of new technology that complements technical problems about safety and security. Therefore, if consumers are feeling insecure about technology, companies should reduce consumer's anxiety by increasing reliability of mobile payments. Solving this problem will be essential for use diffusion and acceptance of new technologies in the future.

In view of the above research results and their implications, technology anxiety appears to be an important factor influencing use diffusion patterns, satisfaction, and interest in future technology. It can be explained that anxiety in the use of technology must be resolved in order to increase the satisfaction of consumers. Dissatisfaction with existing mobile payments leads to a desire for a new technology that can relieve such anxiety. Therefore, an in-depth study on consumer's technology anxiety is needed in the future, which is expected to contribute to preparing a plan for resolving technology anxiety. Also, there is a limitation that analysis by user types in use diffusion model had not been carried out. Therefore, it is also needed to analyze the use of mobile payments by consumer types in the future researches. 


\section{References}

[1] https://zdnet.co.kr/view/?no=20200610100735, Jun 10 (2020)

[2] https://www.epnc.co.kr/news/articleView.html?idxno=105443, Oct 20 (2020)

[3] Turner, M., Kitchenham, B., Brereton, P., Charters, S. and Budgen, D., Does the technology acceptance model predict actual use? A systematic literature review, Information and Software Technology, (2010), Vol.52, No.5, pp.463-479.

[4] J. Li, J. L. Liu, H. Y. Ji, Empirical study of influence factors of adaption intention of mobile payment based on TAM model in China, International Journal of u-and e-Service, Science and Technology, (2014), Vol.7, No.1, pp.119-132.

[5] J. Li, J. Wang, S. Wangh, Y. Zhou, Mobile payment with alipay: An application of extended technology acceptance model, IEEE Access, (2019), Vol.7, pp.50380-50387.

[6] K. Li, X. Sun, Y. J. Yan, Factors influencing the willingness to use mobile payment system: an empirical study based on exchange theory, Management Review, (2013), Vol.25, No.3, pp.91-100.

[7] C. F. Shih, A.Venkatesh, Beyond adoption: Development and application of a use-diffusion model, Journal of Marketing, (2004), Vol.68 No.1, pp.59-72.

[8] W. W. Jiang, The Characteristic and The Perception of the Mobile Payment Technology of Chinese Consumers, Ewha Womans University, Master's Thesis, (2019)

[9] K. E. Maull, M. G. Saldivar, T. Sumner, Understanding digital library adoption: a use diffusion approach, The 11th annual international ACM/IEEE joint conference on Digital libraries, (2011), June 13-17; Ottawa, Ontario, Canada

[10] D. G. Soopramanien, A. Robertson, Adoption and usage of online shopping: An empirical analysis of the characteristics of "buyers" "browsers" and "non-internet shoppers, Journal of Retailing and Consumer Services, (2007), Vol.14, No.1, pp.73-82.

[11] D. H. Jung, H. S. Chang, K. O. Park, A Study on the Environment Characteristics and Continuous Usage Intention for Improvement of Fintech, The Journal of Information Systems, (2017), Vol.26, No.26, pp.123-142.

[12] J. E. Jung, Y. H. Bahn, A Study on Analytical Comparison between Payment Processes by Different Mobile Payment Types - Focus on Types of Mobile Payment Schemes Used in Korea -, Korea Digital Design Society, (2014), Vol.14, No.2, pp.641-650.

[13] H. B. Ham, C. Y. Choi, The Research on Accepting Attitudes of Financial Consumers for Mobile Payment Systems, The e-Business Studies, (2016) Vol.17, No.6, pp.175-189.

[14] J. W. Hong, S. B. Park, K. Y. Ok, The Moderating Effects of Innovativeness and Absorptive Capacity Between Personal Information Protection Attitude and Mobile Banking Acceptance, Journal of Multimedia Services Convergent with Art, Humanities, and Sociology, (2016), Vol.6, No.6, pp.31-40.

[15] H. Y. Oh, A Study of Factors Affecting the Adoption Intention of Mobile Easy Payment Service, Journal of Financial Consumers, (2015), Vol.5, No.1, pp.33-64.

[16] S. Y. Kim, S. H. Lee, H. S. Hwang, A Study of Factors Affecting Attitude Towards Using Mobile Cloud Service, Journal of the Korea Industrial Information Systems Research, (2013), Vol.18, No.6, pp.83-94.

[17] J. P. Woo, Concepts and Understandings of Structural Equation Models, Korea: Hannarae publishing co., (2013)

[18] P. M. Bentler, Comparative fit indexes in structural models, Psychological Bulletin, (1990), Vol.107, No.2, pp.238246.

[19] K. A. Bollen, J. S. Long, Testing structural equation models, USA: Sage, (1993)

[20] J. F. Hair, W. C. Black, B. J. Babin, R. E. Anderson, R. Tatham, Multivariate data analysis, USA: Pearson Prentice Hall, (2006) 